\title{
Development of a System for increasing the Level of Vehicle Service at the Grain Terminal
}

\author{
Elena Veremeenko ${ }^{1 *}$ \\ ${ }^{1}$ Don State Technical University, 1 Gagarina sq., Rostov-on-Don, 344000, Russia
}

\begin{abstract}
A system of measures allowing to improve the level of vehicle services at the grain terminal was developed. The composition of the considered system includes the following measures: "Grain Terminal" simulation model of service of vehicles, a program for implementation of the pre-registration of vehicles in the terminal, pre-parking, waiting for service and the algorithm of vehicular transport management using radio frequency identification (RFID) technology.
\end{abstract}

\section{Introduction}

The relevance of the topic under consideration is due to the fact that the Russian Federation is among the leading grain exporters in the world. At the end of 2016, the cost of grain export from the Russian Federation was about 6 billion dollars. Our country exports almost all types of cereals, but the largest volumes fall on wheat $(72.5 \%$ in the total volume of Russian grain export), corn (15.4\%) and barley (8.3\%) at the end of 2016. The share of the southern regions of the country (Krasnodar and Stavropol Territory, Rostov Region) in the total volume of export supplies exceeds $80 \%$.

\section{Material and methods}

The most preferred mode of transportation in these export deliveries is the maritime, which requires the coordination of the operation of seaports with incoming grain flows, most of which are carried out by road $[1,2,3]$.

A characteristic feature of transportation of grain crops is the seasonal nature of their harvesting and transportation. This entails a one-time arrival to the territory of the sea terminal of the port of more vehicles than it is able to service based on the production and technological characteristics of the existing equipment. The fact that most terminals have undeveloped information support for the servicing trucks is negatively affects the process of servicing trucks. The facts described above lead to the formation of delays in servicing and queues of trucks.

The negative effect of the appearance of such queues is manifested in the following:

- the throughput of motor roads is reduced;

- the ecological situation is deteriorating;

*Corresponding author: lena_dedyaeva@mail.ru 
- there is unauthorized parking of heavy vehicles on the territory of the city and federal highways;

- emergency situations are created;

- there is a risk of spoilage and theft of cargo;

- the traffic rules are violated, etc.

The actual task is the informational support of the process of servicing vehicles at grain terminals of seaports and to develop a system for integrated management of the flow of vehicles entering the terminal.

\section{Theory}

To achieve this task, the operation of the five largest grain terminals in the Rostov region (Rostov-on-Don: "Bratiya" PCF, "BUNGE CIS" LLC (Bunge), MZK-Rostov LLC, and for the city of Azov: "Promexpeditsiya" LLC, Port elevator of "Razgulay-Zerno" company) was analysed [4]. The technical characteristics of the operation of the terminals were considered, as well as the temporary characteristics of the service of the vehicles at them (Table 1). Based on the obtained statistical data, a simulation model was built that calculates the main indicators of servicing vehicles in the seaport.

Table 1. Indicators of operation of grain terminals in the Rostov region

\begin{tabular}{|c|c|c|c|c|c|c|c|c|c|}
\hline \multirow[b]{2}{*}{$\begin{array}{l}\text { No. } \\
\text { i.i. }\end{array}$} & \multirow[b]{2}{*}{$\begin{array}{l}\text { The name of the } \\
\text { terminal and its } \\
\text { location }\end{array}$} & \multirow[b]{2}{*}{$\begin{array}{l}\text { Types of } \\
\text { cargoes }\end{array}$} & \multicolumn{3}{|c|}{$\begin{array}{c}\text { Technical } \\
\text { characteristics }\end{array}$} & \multicolumn{4}{|c|}{ Time characteristics } \\
\hline & & & 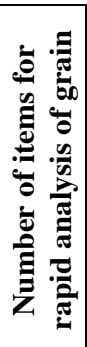 & 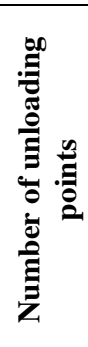 & 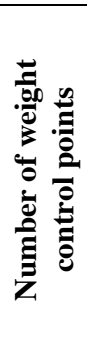 & 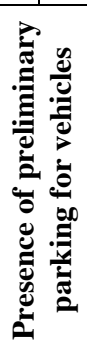 & 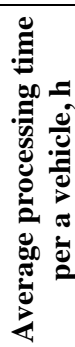 & 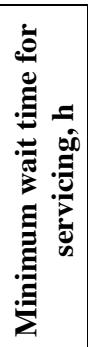 & 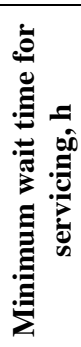 \\
\hline 1 & "Bratiya" PCF & $\begin{array}{c}\text { cereal } \\
\text { oilseeds }\end{array}$ & 2 & 2 & 2 & no & 1 & 2 & 48 \\
\hline 2 & $\begin{array}{l}\text { "BUNGE CIS" LLC } \\
\text { (Bunge), }\end{array}$ & $\begin{array}{c}\text { cereal } \\
\text { oilseeds }\end{array}$ & 1 & 2 & 1 & no & 1 & 2 & 48 \\
\hline 3 & MZK-Rostov LLC & cereals & 2 & 5 & 2 & yes & 1 & 2 & 72 \\
\hline 4 & $\begin{array}{l}\text { "Promexpeditsiya" } \\
\text { LLC }\end{array}$ & cereals & 2 & 5 & 2 & yes & 0.5 & 1 & 96 \\
\hline 5 & $\begin{array}{c}\text { Port elevator of } \\
\text { "Razgulay-Zerno" } \\
\text { company }\end{array}$ & cereals & 2 & 5 & 2 & no & 1 & 4 & 48 \\
\hline
\end{tabular}

The simulation model reflects the movement of the truck through the territory of the grain terminal, according to the following order of operations: registration at the entrance - express analysis of grain - weighing with a cargo - unloading - weighing without a cargo $[5,6,7]$.

To increase the level of servicing vehicles of the port, it is proposed to introduce the following measures:

1. Vehicle management system using the Radio Frequency Identification (RFID).

The measure will allow to automate the process of gathering information on servicing vehicles. At the time of arrival of the vehicle to the terminal, the management system forms 
the RFID-labels with information about the cargo and the vehicle, and then a reader reads this information from the tag at the each processing stations. The data obtained are recorded online in the database of the control system, in particular, this is the exact time of arrival of the vehicle, the time of leaving the service station, as well as the duration of service. Using the data from this database, the system forms a route for the next vehicle [8].

2. The software complex "System of pre-registration of vehicles at the terminal".

It implements the above described system of vehicle management, which allows also to determine the recommended time of arrival of vehicles to the terminal. This software package is placed on the terminal's official web-site and allows remote registration in the electronic queue via the Internet. This opportunity is especially relevant for transport arriving in the Rostov region from other regions of the Russian Federation. Knowing in advance the scheduled service time, transport owners have the opportunity to optimize its operation and reduce downtime. This tool makes it possible to implement the management impact on the trucking of grain crops throughout the entire logistics chain.

The most important functionality of the program:

- the possibility of calculation the estimated duration of operations for servicing vehicles for the next day based on the results of the current day;

- the possibility of determination of the most optimal fixed interval for the arrival of vehicles to the terminal, which allows you to take into account several parameters at a time: waiting time for vehicles to start servicing; the number of vehicles serviced per day; the cost of a long wait by vehicles; port losses due to the incomplete use of equipment capacities;

- the ability to promptly make changes in the occurrence of abnormal factors in the external and internal environments of the terminal.

3. Mandatory pre-parking for vehicles.

As was shown by the analysis of the grain terminals in the Rostov region, only the two largest terminals are equipped with a pre-parking for trucks. It is necessary to mandatory organize parking for each terminal, this measure allows to exclude the negative effect of the emergence of seasonal queues from trucks near the terminals. Also, the pre-parking allows to create a "buffer stock" of vehicles, which allows to reduce losses of the port from equipment downtime due to non-observance of the transport arrival schedule $[9,10]$.

\section{Results and discussion}

The results of simulation showed that the above measures aimed at increasing the level of servicing vehicles form a closed system, as they are closely interrelated and exert a direct influence on each other (Figure 1). The refusal to implement any of the measures considered will lead to incorrect operation of the entire system. The above arguments indicate that the system under consideration has a synergistic effect [11, 12]. 


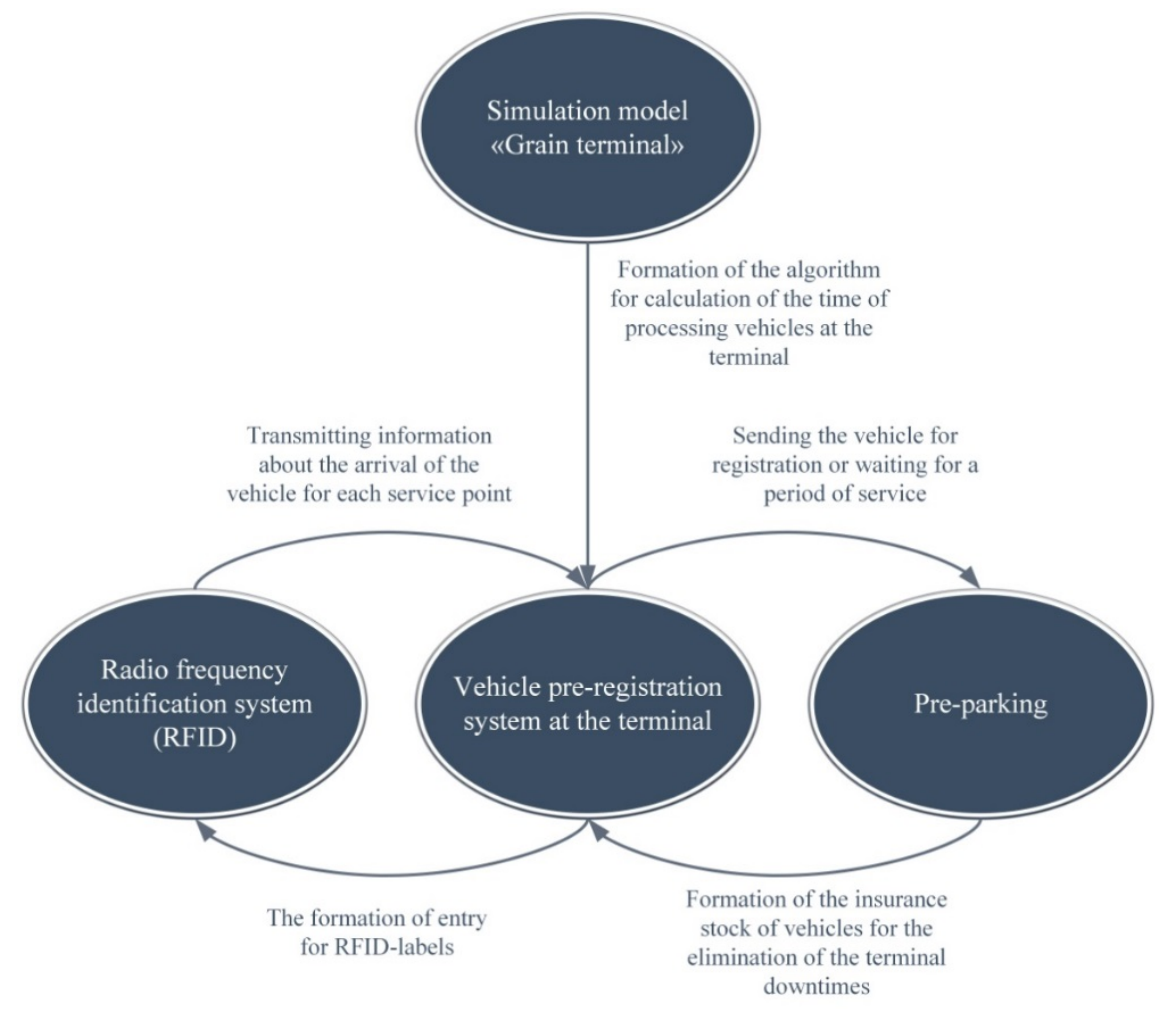

Fig. 1. System of measures to improve the level of servicing vehicles at the grain terminal.

Let us consider the expected results of the terminal operation after the introduction of the proposed improvements [13]:

- the number of serviced trucks increased from 95 to 128 per day;

- the average service time of one vehicle was reduced from 95 minutes up to $80 \mathrm{~min}$;

- the level of servicing vehicles increased by $25 \%$ (from $72 \%$ to $97 \%$ ).

I would like to particularly emphasize that due to the increase in the number of serviced vehicles per day, the level of servicing vehicles has significantly grown, which means the ratio of the actual volume of services to the theoretically possible, which was the declared goal of the paper $[14,15]$.

\section{Conclusion}

In conclusion, I want to note that the presented paper is aimed at solving the theoretical, methodological and practical problems of ensuring effective interaction of road transport and grain terminals of the seaports of the Azov-Black Sea basin when exporting grain. Based on the results of the research, a system was developed for management of the transportation of grain, increase of the capacity of the grain terminal, and reduction of downtime of vehicles in queues.

\section{References}

1. E. Zaitsev, Information technologies and systems in logistics and supply chain management. Moscow, 2010. 
2. V. Zyryanov, V. Kocherga, I. Topilin Investigation of dependencies between parameters of two-component models of the kinetic theory of traffic flow and traffic characteristics. Transportation Research Procedia, pp. 746-750 (2017)

3. S. Zhankaziev, Intelligent transport system on the roads of Russia. Interindustry Journal of Navigation Technologies GLONASS Bulletin, 2. pp. 7-11 (2011)

4. A. Veremeenko, E. Veremeenko, Problems of interaction between the port and road transport. The engineer bulletin of Don, T. 25, 2 (25), P. 117 (2013)

5. V. Zyryanov, A. Feofilova, Simulation of Evacuation Route Choice. Transportation Research Procedia, 20, pp. 740-745 (2017)

6. T. Rogovenko, M. Zaitseva, Use of statistical simulation in construction planning. MATEC Web of Conferences, 106, 08011 (2017)

7. V. Golenkov, A. Novikov, A. Katunin, Yu. Baranov, D. Matnazarov, Optimization of traffic management based on simulation. Science and technology in the road industry, 3 (73), pp. 5-7 (2015)

8. E. Veremeenko, The use of radio frequency identification (RFID) system for automation of road transport operating in the port. The engineer bulletin of Don, $\mathrm{T}$. 27, 4, pp. 237-240 (2013)

9. V. Kurganov, Macroeconomic assessment of transport capacity. Laws of logistics and statistical regularities. Tver (2013)

10. V. Fialkin, E. Veremeenko, Characteristics of Traffic Flow Management in Multimodal Transport Hub (by the Example of the Seaport). Transportation Research Procedia, 20, pp. 205-211 (2017)

11. V. Zyryanov, Methods for assessing the adequacy of modeling results. The engineer bulletin of Don, T. 25, 2 (25), P. 132 (2013)

12. V. Korchagin, A. Novikov, S. Lyapin, Yu. Rizaeva, Complex self-developing transport systems. The world of transport and technological machines, 2 (53), pp. 110-116 (2016)

13. E. Veremeenko, Increase the efficiency of interaction between road transport and the cargo terminal. Scientific review, 11-3, pp. 931-933 (2014)

14. V. Kurganov, M. Gryaznov, A. Dorofeev, Information support reliability of transportation systems in the industry. ACM International Conference Proceeding Series 7. "ICICM 2017 - Proceedings of the 7th International Conference on Information Communication and Management", pp. 162-167 (2017)

15. D. Bowersox, D. Closs, Logistical Management. The Integrated Supply Chain Process. Moscow: CJSC Olymp-Business (2008) 